\title{
ANALISIS USAHA PENGOLAHAN KOPI JAHE INSTAN DI TERNATE
}

\author{
Yonette Maya Tupamahu \\ Staf Pengajar FAPERTA UMMU-Ternate, e-mail : ymtup@yahoo.co.id
}

\begin{abstract}
ABSTRAK
Penelitian bertujuan untuk mengetahui proses produksi kopi jahe instan, mengetahui besarnya keuntungan industri kecil, dan menganalisis besarnya nilai tambah pengolahan kopi jahe instan. Metode analisis data yang digunakan yaitu teknik analisis kualitatif mengenai proses produksi kopi jahe instan dan analisis kuantitatif, yaitu analisis pendapatan dan nilai tambah Metode Hayami. Hasil penelitian menunjukkan proses produksi kopi jahe instan adalah : a) kopi dan jahe dicuci bersih lalu jahe dikupas dan diiris; b) kopi dan jahe dijemur; c) kopi dan jahe disangrai secara terpisah; d) kopi dan jahe digiling secara terpisah hingga menjadi bubuk; e) bubuk kopi dan jahe dicampur; f) pengemasan; g) pemasaran. Besarnya pendapatan industri kecil kopi jahe instan adalah $R p$ 103.706.496per tahun. Nilai tambah yang diperoleh dari pengolahan $1 \mathrm{~kg}$ bahan baku kopi jahe adalah $\mathrm{Rp}$. 26.355,52 per $\mathrm{kg}$. Nilai tambah yang diperoleh masih merupakan nilai tambah kotor, karena belum dikurangi dengan imbalan tenaga kerja. Rasio nilai tambah yang diperoleh yaitu $57,29 \%$, berarti dalam pengolahan kopi dan jahe menjadi produk bubuk kopi jahe, memberikan nilai tambah sebesar $57,29 \%$ dari nilai produk. Imbalan tenaga kerja pengolahan kopi jahe yaitu sebesar Rp 4.750 atau 18,02 \% dari nilai tambah. Sedangkan keuntungan adalah sebesar $R p 21.605,52$ atau $81,98 \%$ dari nilai produk.
\end{abstract}

Kata Kunci: pengolahan kopi jahe, pendapatan, nilai tambah

\section{PENDAHULUAN}

\subsection{Latar Belakang}

Kopi merupakan komoditi perkebunan utama di Indonesia dimana produk sekundernya yaitu kopi bubuk digemari oleh masyarakat. Kopi mengandung kafein, yang dalam dosis rendah dapat mengurangi rasa lelah dan membuat pikiran jadi segar. Menurut ICCRI (2014) biji kopi secara alami juga mengandung senyawa yang bersifat antioksidan yang bisa meningkatkan resistensi tubuh melawan berbagai penyakit degeneratif seperti kanker, asam urat, dan diabetes. Saat ini pengolahan kopi mengalami perubahan terkait dengan selera konsumen, dimana bubuk kopi sudah ditambah bahan-bahan lainnya sehingga ada citarasa baru.

Industri pengolahan kopi di Indonesia beragam yakni dari industri rumah tangga hingga industri besar. Produk-produk yang dihasilkan salah satunya untuk memenuhi kebutuhan konsumsi kopi dalam negeri. Hal tersebut menunjukkan bahwa konsumsi kopi di dalam negeri merupakan pasar yang menarik bagi kalangan pengusaha. Konsumsi kopi di Indonesia per kilogram per kapita per tahun mengalami peningkatan seiring kenaikan jumlah penduduk, sebagaimana tersaji pada Tabel 1 (AEKI, 2013).

Konsumsi kopi mengalami pergeseran khususnya pada kawula muda, hal ini terkait dengan meningkatnya taraf hidup dan pergeseran gaya hidup masyarakat perkotaan di Indonesia. Generasi muda pada umumnya lebih menyukai minum kopi instant, kopi three in one maupun minuman berbasis expresso yang disajikan di café-café (AEKI, 2013). Salah satu minuman kopi yang mulai banyak dikonsumsi adalah kopi jahe instan dimana ketika diseduh tidak terdapat residu/ampas, 
yang dibuat dari pengolahan kopi dan ditambah dengan jahe.

Jahe (Zingiber officinale) merupakan tanaman rimpang yang sangat populer sebagai rempah-rempah dan bahan obat, dan memiliki rasa dominan pedas disebabkan senyawa keton bernama zingeron(Wikipedia, 2013). Secara umum pengolahan kopi jahe yaitu kopi dan jahe dikeringkan selanjutnya digiling dengan kehalusan butiran bubuk yang ditentukan

Tabel 1. Konsumsi Kopi di Indonesia

\begin{tabular}{ccc}
\hline Tahun & Jumlah Penduduk (juta jiwa) & $\begin{array}{c}\text { Konsumsi Kopi } \\
\text { (kg/kapita/tahun) }\end{array}$ \\
\hline 2010 & 237 & 0,80 \\
2011 & 241 & 0,87 \\
2012 & 245 & 0,94 \\
$2013^{* *}$ & 249 & 1,00 \\
$2014^{* *}$ & 253 & 1,03 \\
$2015^{* *}$ & 257 & 1,09 \\
$2016^{* *}$ & 300 & 1,15 \\
\hline
\end{tabular}

Keterangan : ${ }^{* *}=$ estimasi

Sumber : AEKI atau Asosiasi Eksportir dan Industri Kopi Indonesia (2013)

Penambahan jahe ini sangat bermanfaat disebabkan jahe dapat menghangatkan badan serta menambah nafsu makan. Menurut Koswara (1995), jahe dapat merangsang kelenjar pencernaan, baik untuk membangkitkan nafsu makan dan pencernaan. Hal ini dimungkinkan karena terangsangnya selaput lendir perut besar dan usus oleh minyak asiri yang dikeluarkan rimpang jahe. Minyak jahe berisi gingerol yang berbau harum khas jahe, berkhasiat mencegah dan mengobati mual dan muntah. Sehingga kopi jahe ini sangat cocok diminum pada saat udara yang dingin karena dapat menyegarkan dan menghangatkan badan.

Pengolahan kopi jahe menunjukkan adanya peningkatan nilai tambah kopi. Nilai tambah (value added) adalah suatu komoditas yang bertambah nilainya karena melalui proses pengolahan, pengangkutan ataupun penyimpanan dalam suatu produksi. Dari pengertian ini definisi nilai tambah adalah selisih lebih antara nilai produk dengan nilai biaya input, tidak termasuk upah tenaga kerja.

Selain nilai tambah, pengolahan kopi juga dapat memberikan keuntungan bagi industri yang mengusahakannya. Khusus di Kota Ternate, jumlah perusahaan yang melakukan pengolahan kopi ada 4 perusahaan, dengan jumlah tenaga kerja 15 orang, dan nilai investasi sebesar Rp 37.150.000 (BPS Kota Ternate, 2013). Namun demikian hanya ada satu industri kecil yang memproduksi kopi jahe instan, yaitu UD. Kopi Gamalama Ternate.
Usaha yang dijalankan oleh industri kecil kopi jahe instan ini pun memiliki kendala-kendala, yaitu: pertama, bahan baku kopi dibeli secara langsung di Kecamatan Ibu (Kabupaten Halmahera Barat) dengan jalur laut dan darat, sehingga menambah biaya produksi. Kedua, terbatasnya modal usaha yang berdampak terbatasnya pembelian bahan baku, serta peralatan dan teknologi yang digunakan pun minim. Ketiga, kemasan produk tidak menarik dimana label kemasan dicetak sendiri. Dan keempat, produk dipasarkan hanya di toko-toko atau swalayan dan supermarket dengan sistim titip, yaitu bilamana saat produk tidak terjual maka barang akan dikembalikan. Berbeda ketika pedagang membeli secara langsung, maka segala resiko kerusakan ditanggung pedagang. Kondisi ini sejalan dengan pendapat tim dosen STIE YKPN (2001), bahwa faktor-faktor yang mempengaruhi perkembangan usaha kecil dalam upaya meningkatkan keuntungan yaitu: pengalaman, modal, lokasi, lembaga demografis konsumen, strategi manajemen persediaan, dan administrasi keuangan

Kendala yang juga dirasakan industri kecil ini adalah menghadapi persaingan dengan produk-produk kopi lainnya yang bermerek dan sudah dikenal oleh masyarakat. Menurut Maulana (2005), kopi instan yang ada pada saat ini sudah diterima oleh masyarakat, disebabkan oleh dua faktor, yaitu produsen membangun persepsi konsumen bahwa produk kopi instan adalah, jenis minuman yang 
menawarkan kepraktisan dalam penyajiannya, dan tidak menyisakan serbuk kasar atau ampas bila diminum. Serta kepandaian produsen lewat iklan, dimana kopi instan identik dengan kultur masyarakat kota, masyarakat modern, dan masyarakat yang selalu disibukkan oleh beragam jenis pekerjaan yang menghabiskan waktu.

Berbagai kendala yang dihadapi tentunya akan mempengaruhi usaha pengolahan kopi jahe, seperti besarnya perolehan keuntungan serta besarnya nilai tambah dari bahan baku kopi dan jahe. Sebab itu perlu dilakukan kajian usaha pengolahan kopi jahe instan meliputi: bagaimana proses pengolahannya, seberapa besar keuntungan yang diperoleh industri kecil, dan seberapa besar nilai tambah pengolahan kopi jahe instan.

\subsection{Tujuan Penelitian}

Penelitian ini mempunyai tujuan untuk:

1. Mengetahui proses produksi kopi jahe instan.

2. Mengetahui besarnya keuntungan industri kecil kopi jahe instan.

3. Menganalisis besarnya nilai tambah pengolahan kopi dan jahe instan.

\section{METODE PENELITIAN}

2.1. Jenis dan Teknik Pengumpulan Data

Penelitian ini menggunakan jenis data primer dan sekunder. Data primer diperoleh dari pengamatan langsung kegiatan produksi dan pemasaran di industri rumah tangga, wawancara langsung denganpemilik (manager) mengenai aspek pemasaran, keuangan, produksi sumberdaya manusia dan proses pengembangan usaha, serta pengisian kuesioner.

Data Sekunder diperoleh melalui studi pustaka dan literatur yang berkaitan dengan penelitian, yang bersumber dari Badan Pusat StatistikKota Ternate, Dinas Perindustrian Propinsi Maluku Utara dan Kota Ternate, jurnal atau pustaka ilmiah yang mendukung topik penelitian, dan buku teks.

\subsection{Metode Pengambilan Sampel}

Penelitian merupakan studi kasus pada industri kecil UD. Kopi Gamalama Ternate dan dilaksanakan pada bulan April - Mei 2012.
Pemilihan lokasi ini dilakukan secara sengaja (purposive), pertimbangannya karena perusahaan ini merupakan satu-satunya industri kecil yang memproduksi kopi jahe instan.

\subsection{Metode Analisis Data}

Ada dua teknik analisis data yang digunakan yaitu teknik analisis kualitatif dan kuantitatif (Rianse, dkk., 2009). Analisis kualititatif untuk menjawab tujuan penelitian pertama, yaitu menjelaskan berbagai fakta yang terindentifikasi dalam proses produksi kopi jahe dan pemasarannya. Sedangkan analisis kuantitatif untuk menjawab tujuan penelitian kedua dan ketiga, dimaksudkan untuk menganalisis data yang berbentuk angka yaitu analisis pendapatan dan nilai tambah.

Perhitungan pendapatan menggunakan rumus sebagai berikut :

$$
\begin{aligned}
& \mathrm{TC}=\mathrm{FC}+\mathrm{VC} \\
& \mathrm{TR}=\mathrm{x} . \mathbf{P x} \\
& \pi=\mathrm{TR}-\mathrm{TC}
\end{aligned}
$$

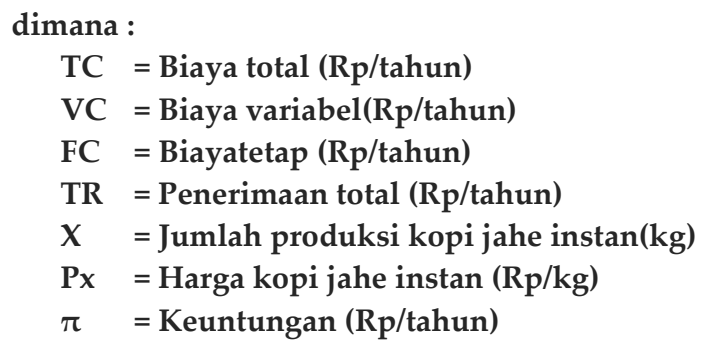

Perhitungan nilai tambah menggunakan metode Hayami et al (1987) (Tabel 2).

\section{HASIL DAN PEMBAHASAN}

3.1. Proses Produksi dan Pemasaran Kopi Jahe Instan

Proses produksi merupakan tahapan kerja pengolahan bahan baku sampai pada keadaan tertentu dan atau pemasaran hasil (Gambar 1).

Jumlah produksi kopi jahe yang mampu dihasilkan oleh industri kecil ini sebesar $200 \mathrm{~kg}$ per bulan. Tahap awal adalah bahan baku kopi dan jahe dibersihkan dari kotoran yang menempel seperti tanah dan semak-semak kering yang terbawa dan atau yang menempel. Jahe yang bersih lalu diiris-iris dengan ukuran kurang lebih $1 \mathrm{~cm}$, tujuannya untuk 
mempermudah proses penggilingan, setelah itu kopi dan jahe dijemur kurang lebih 3 hari menggunakan alat pemotongan manual, yaitu dibawah sinar matahari. Pada tahap ini masih

Tabel 2. Format Perhitungan Nilai Tambah Metode Hayami

\begin{tabular}{cll}
\hline No & \multicolumn{1}{c}{ Variabel (Output, Input, Harga) } & \multicolumn{1}{c}{ Notasi } \\
\hline I. & Output, Input dan Harga & $(1)$ \\
1 & Hasil/produksi (kg/tahun) & $(2)$ \\
2 & Bahan baku (kg/tahun) & $(3)$ \\
3 & Tenaga kerja (HOK/tahun) & $(4)=(1) /(2)$ \\
4 & Faktor konversi (1/2) & $(5)=(3) /(2)$ \\
5 & Koefisien tenaga kerja (3/2) & $(6)$ \\
6 & Harga produk rata-rata (Rp/kg) & $(7)$ \\
7 & Upah rata-rata (Rp/kg) & $(8)$ \\
\hline II. & Penerimaan dan Keuntungan & $(9)$ \\
8 & Harga bahan baku (Rp/kg) & $(10)=(4) \times(6)$ \\
9 & Sumbangan input lain (Rp/kg)* & $(11 \mathrm{a})=(10)-(9)-(8)$ \\
10 & Nilai produk (Rp/kg) (4x6) & $(11 \mathrm{~b})=(11 \mathrm{a} / 10) \times 100 \%$ \\
11 & a. Nilai tambah (Rp/kg) (10-8-9) & $(12 \mathrm{a})=(5) \times(7)$ \\
12 & b. Ratio nilai tambah (\%) $(11 \mathrm{a} / 10)$ & $(12 \mathrm{~b})=(12 \mathrm{a} / 11 \mathrm{a}) \times 100 \%$ \\
13 & a. Imbalan tenaga kerja (Rp/hk) $(5 \times 7)$ & $(13 \mathrm{a})=(11 \mathrm{a})-(12 \mathrm{a})$ \\
& b. Bagian tenaga kerja (\%) $(12 \mathrm{a} / 11 \mathrm{a})$ & $(13 \mathrm{~b})=(13 \mathrm{a} / 11 \mathrm{a}) \times 100 \%$ \\
\hline
\end{tabular}

Keterangan:

* = bahan penolong

** = imbalan bagi modal dan manajemen.

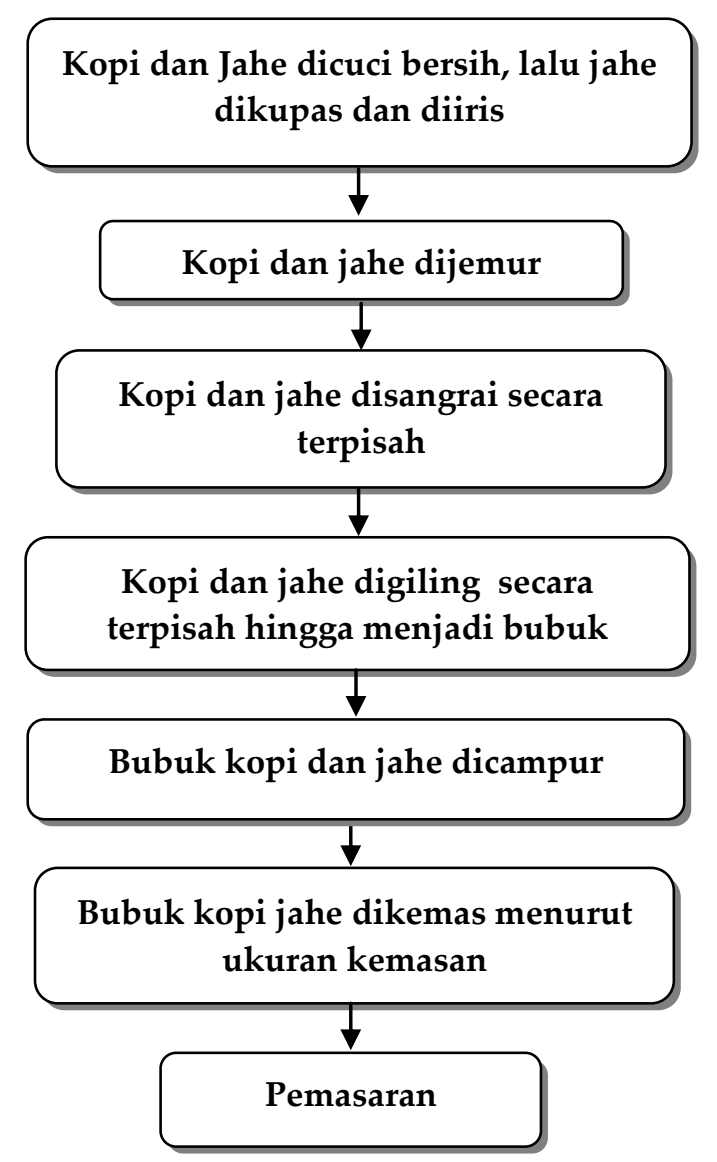

Gambar 1. Proses Produksi Pengolahan Kopi Jahe Instan 
Kopi dan jahe yang sudah kering lalu disangrai terpisah selama 15 menit yang bertujuan untuk mematangkan bahan baku. Setelah itu didinginkan baru kemudian dilakukan penggilingan. Proses ini berlangsung selama 1 jam dengan menggunakan mesin penggiling secara terpisah antara kedua bahan baku hingga benar-benar halus, sehingga ketika diseduh tidak terdapat bahan baku yang masih kasar (berampas). Tahap berikutnya adalah proses pencampuran bubuk kopi dan jahe, untuk menghasilkan produk kopi jahe.

Proses pencampuran selesai dilanjutkan ketahap pengemasan produk dimana kopi jahe dikemas dalam plastik bening dengan ketebalan standar dan diberi label merek kopi jahe. Tujuannya untuk menarik minat konsumen, namun demikian kemasan masih sederhana bila dibandingkan dengan produk sejenis lainnya.

Tahap terakhir adalah produk siap dipasarkan, tetapi hanya berkisar di Kota Ternate saja. Proses pemasarannya tidak secara langsung ke konsumen namun menggunakan jasa lembaga pemasaran melalui toko, swalayan baru ke konsumen. Sebelumnya produsen melakukan kerja sama dengan toko/swalayan tersebut, atau melakukan produk dipasarkan sistim titip dimana setelah produk terjual baru diambil uangnya.

\subsection{Analisis Keuntungan}

Besarnya keuntungan yang diperoleh dari pengolahan kopi jahe tersaji pada Tabel 3.

Tabel 3. Keuntungan Industri Kecil Kopi Jahe Instan dalam 1 tahun

\begin{tabular}{lcc} 
& Uraian & Nilai (Rp) \\
\hline Biaya Total & 117.093 .504 \\
Penerimaan & 220.800 .000 \\
Keuntungan & 103.706 .496 \\
\hline
\end{tabular}

Sumber: Data primer diolah, 2012

Tabel 2 memperlihatkan bahwa penerimaan lebih besar dari total biaya produksi yang dikeluarkan, artinya bahwa industri kecil kopi jahe tidak mengalami kerugian. Perolehan keuntungan sebesar Rp 103.706.496 per tahun atau $R p$ 8.642.208 per bulan masih dapat ditingkatkan jika produsen dapat mengembangkan strategi pemasarannya, seperti penjualan produk kopi jahe ke wilayah lain. Hal ini sejalan dengan David (2006) ketika ada pasar yang belum tersentuh serta perusahaan bersaing dalam satu industri, yang memiliki perkembangan teknologi yang cepat, maka strategi yang efektif adalah pengembangan pasar dan pengembangan produk.

\subsection{Analisis Nilai Tambah}

Nilai tambah (value added) adalah pertambahan nilai suatu komoditas karena mengalami proses pengolahan, pengangkutan ataupun penyimpanan dalam suatu produksi. Dalam proses pengolahan nilai tambah dapat didefinisikan sebagai selisih antara nilai produk dengan nilai biaya bahan baku dan input lainnya, tidak termasuk tenaga kerja.
Sedangkan marjin adalah selisih antara nilai produk dengan harga bahan bakunya saja. Dalam marjin ini tercakup komponen faktor produksi yang digunakan yaitu tenaga kerja, input lainnya dan balas jasa pengusaha pengolahan (Hayami et al, 1987). Analisis nilai tambah akan memberikan informasi mengenai faktor-faktor dari proses produksi yang menghasilkan atau meningkatkan nilai tambah. Hasil analisis nilai tambah industri kecil kopi jahe dapat dilihat pada Tabel 4.

Berdasarkan hasil analisis pada Tabel 4 terlihat bahwa jumlah produksi bubuk kopi jahe yang dihasilkan per tahun sebesar 2.400 kg. Produk yang dihasilkan tersebut membutuhkan $2.400 \mathrm{~kg}$ kopi dan $2.400 \mathrm{~kg}$ jahe atau totalnya $4.800 \mathrm{~kg}$ bahan kopi jahe per tahun, sehingga faktor konversinya adalah 0,5. Hal ini menunjukkan setiap satu kilogram kopi dan jahe yang diolah akan menghasilkan 0,5 kg bubuk kopi dan jahe.

Jumlah tenaga kerja yang digunakan sebanyak 4 orang dengan jumlah hari kerja selama 7 jam per hari, serta jumlah hari kerja efektif selama satu tahun adalah 168 hari. Dengan demikian nilai input tenaga kerja 
sebesar $588 \mathrm{HOK} /$ tahun sehingga diperoleh nilai koefisien tenaga kerja 0,12 , yang berarti bahwa untuk mengolah 1 kilogram bahan baku kopi dan jahe dibutuhkan tenaga kerja per
HOK sebesar $R p \quad 38.775,51$. Harga produk sebesar Rp 92.000 per kilogram, merupakan harga jual di tingkat produsen.

Tabel 4. Analisis Nilai Tambah Pengolahan Kopi Jahe Instan dalam 1 Tahun

\begin{tabular}{clr}
\hline No & \multicolumn{1}{c}{ Variabel (output, input, harga) } & Nilai \\
\hline 1 & Hasil/produksi (kg/tahun) & 2400 \\
2 & Bahan baku (kg/tahun) & 4800 \\
3 & Tenaga kerja (HOK/tahun) & 588 \\
4 & Faktor konversi & 0,5 \\
5 & Koefisien tenaga kerja & 0,12 \\
6 & Harga produk rata-rata (Rp/kg) & 92.000 \\
7 & Upah rata-rata (Rp/HOK) & $38.775,51$ \\
\hline No & $\quad$ Penerimaan dan Keuntungan & Nilai \\
\hline 8 & Harga bahan baku (Rp/kg) & 16.500 \\
9 & Sumbangan input lain (Rp/kg) & $3.144,48$ \\
10 & Nilai produk (Rp/kg) & 46.000 \\
11 & a. Nilai tambah (Rp/kg) & $26.355,52$ \\
& b. Ratio nilai tambah (\%) & 57,29 \\
12 & a. Imbalan tenaga kerja (Rp/hk) & $4.750,00$ \\
& b. Bagian tenaga kerja (\%) & 18,02 \\
13 & a. Keuntungan (Rp) & $21.605,52$ \\
& b. Tingkat keuntungan (\%) & 81,98 \\
\hline
\end{tabular}

Sumber: Data primer diolah, 2012

Nilai input lain untuk produk kopi jahe sebesar Rp. 3144,48 per $\mathrm{kg}$, diperoleh dari pembagian antara jumlah faktor produksi yang digunakan secara bersama-sama dengan jumlah bahan baku yang digunakan untuk produk. Nilai input lain dalam hal ini ditambah dengan biaya penyusutan, biaya listrik dan air kemudian dibagi dengan banyaknya bahan baku kopi dan jahe yang digunakan untuk satu tahun. Biaya penyusutan, biaya listrik dan air pada pembuatan produk kopi jahe dihitung berdasarkan frekuensi produksi selama 1 tahun.

Nilai produk kopi jahe adalah Rp. 46.000 per $\mathrm{kg}$ yang diperoleh dari perkalian masingmasing faktor konversi dengan harga produk. Nilai ini menunjukkan bahwa setiap pengolahan satu kilogram bahan baku kopi jahe akan menghasilkan Rp. 46.000,00,- per kg. Nilai tambah yang diperoleh dari pengolahan satu kilogram bahan baku kopi jahe adalah Rp. $26.355,52$ per $\mathrm{kg}$. Nilai tambah ini diperoleh dari pengurangan nilai produk dengan harga bahan baku dan nilai input lain. Nilai tambah yang diperoleh masih merupakan nilai tambah kotor, karena belum dikurangi dengan imbalan tenaga kerja.

Rasio nilai tambah merupakan perbandingan antara nilai tambah dengan nilai produk. Rasio nilai tambah yang diperoleh yaitu $57,29 \%$. Hal ini menunjukkan bahwa setiap Rp 100 nilai produk akan diperoleh nilai tambah sebesar Rp 57,29. Nilai tambah dari industri pengolahan ini cukup besar karena harga produk minuman instan kopi jahe yang cukup baik di pasaran.

Imbalan tenaga kerja pengolahan kopi jahe didapat dari perkalian koefisien tenaga kerja dengan upah rata-rata tenaga kerja yaitu sebesar Rp 4.750. Persentase imbalan tenaga kerja terhadap nilai tambah adalah 18,02\%. Keuntungan diperoleh dari pengurangan nilai tambah dengan imbalan tenaga kerja. Besar keuntungan adalah sebesar $\mathrm{Rp} 21.605,52$ atau tingkat keuntungan sebesar $81,98 \%$ dari nilai produk, berarti bahwa distribusi nilai tambah lebih baik dbandingkan dengan dengan bagian keuntungan untuk tenaga kerja. 


\section{KESIMPULAN DAN SARAN}

\subsection{Kesimpulan}

Berdasarkan pembahasan maka dapat disimpulkan :

1. Proses produksi kopi jahe instan adalah : a) kopi dan jahe dicuci bersih lalu jahe dikupas dan diiris; b) kopi dan jahe dijemur; c) kopi dan jahe disangrai secara terpisah; d) kopi dan jahe digiling secara terpisah hingga menjadi bubuk; e) bubuk kopi dan jahe dicampur; f) pengemasan; g) pemasaran.

2. Besarnya pendapatan industri kecil kopi jahe instan adalah $\mathrm{Rp}$ 103.706.496 per tahun.

3. Nilai tambah yang diperoleh dari pengolahan $1 \mathrm{~kg}$ bahan baku kopi jahe adalah Rp. 26.355,52 per kg. Nilai tambah yang diperoleh masih merupakan nilai tambah kotor, karena belum dikurangi dengan imbalan tenaga kerja. Rasio nilai tambah yang diperoleh yaitu $57,29 \%$, berarti dalam pengolahan kopi dan jahe menjadi produk bubuk kopi jahe, memberikan nilai tambah sebesar 57,29\% dari nilai produk. Imbalan tenaga kerja pengolahan kopi jahe yaitu sebesar $\mathbf{R p}$ 4.750 atau 18,02 \% dari nilai tambah. Sedangkan keuntungan adalah sebesar $\mathbf{R p}$ $21.605,52$ atau 81,98 \% dari nilai produk.

4.2 Saran

Adapun saran yang dapat dikemukakan terkait dengan hasil penelitian adalah :

1. Industri kecil dapat meningkatkan besarnya pendapatan dan nilai tambah pengolahan kopi jahe melalui pengembangan produk dan pasar.

2. Perlu adanya bantuan pemerintah bagi industri kecil melalui bantuan penguatan modal serta pemasaran

\section{DAFTAR PUSTAKA}

AEKI, 2013. Industri kopi Indonesia. http://www.aeki-aice.org/page/industri-kopi/id

AEKI, 2013. Konsumsi Kopi Domestik. http://www.aeki-aice.org/page/konsumsi-kopi-domestik/id Badan Pusat Statistik, 2013. Kota Ternate dalam Angka 2013, Badan Pusat Statistik, Ternate.

David, F.R., 2006. Manajemen Strategis: Konsep, Edisi 10 Buku 1, Penerjemah Ichsan S. Budi, Salemba Empat, Jakarta.

Hayami, Y., T, Kawagoe, Y. Morooka dan M. Siregar, 1987. Agricultural Marketing and Processing in Upland Java A Perspective from A Sunda Village, CGPRT Centre, Bogor

ICCRI, 2014. Minum Kopi: Melawan Penyakit Degeneratif. http://iccri.net/minum-kopi-melawanpenyakit-degeneratif/

Koswara, S. 2009. Jahe, Rimpang dengan Sejuta Khasiat. http//Ebookpangan.com

Maulana, A.E., 2005. Konsumen Kopi Instan, Majalah SWA.2005, Edisi 15/XXI/21 Juli - 3 Agustus

Rianse, U. dan Abdi, 2009. Metodologi Penelitian Sosial dan Ekonomi -Teori dan Aplikasi, Alfabeta, Bandung.

Tim Dosen YKPN. 2001. Pengantar Bisnis, STIE YKPN, Yogyakarta. 